\title{
Multidrug Resistant Bacillus cereus in Fresh Vegetables: A Serious Burden to Public Health
}

\author{
Bhavish Sood ${ }^{1}$, Param Pal Sahota ${ }^{1}$ and Mandeep Hunjan ${ }^{2}$ \\ ${ }^{1}$ Department of Microbiology, Punjab Agricultural University, Ludhiana-141004, India \\ ${ }^{2}$ Department of Plant Pathology, Punjab Agricultural University, Ludhiana-141004, India \\ *Corresponding author
}

\section{A B S T R A C T}

\section{Keywords}

Antibiotic

resistance,

B. cereus,

Enterotoxin, Fresh vegetables,

\section{Article Info}

Accepted: 06 March 2017 Available Online: 10 April 2017
The frequent inhabitation of B. cereus in fresh vegetables can critically damage the public health and economics. Fresh vegetables from three sources; Village fields, Supermarkets and Street Vendors were examined for microbiological safety for raw consumption. Among the seven salad vegetables that are integral to daily diet intake were found with high Food MPN count of $>100 \mathrm{~g}^{-1}$ (42.8-100\%), total coliforms $>10 \mathrm{ml}^{-1}$ (75.6-98.5\%), faecal coliforms $>10 \mathrm{ml}^{-1}(59.6-91.2 \%)$. The highest mean count of B. cereus $(4.35 \mathrm{log}$ cfu $\mathrm{g}^{-1}$ ) was found in carrots sourced from Village fields). The ability of Bacillus isolates to lyse erythrocytes can directly be correlated with the expression of haemolytic enterotoxin. Antibiotic resistance of Bacillus cereus isolates to four or more antibiotics may bud a serious perturbation in treating associated illness. Effectiveness of aminoglycoside, fluoroquinone, tetracycline and glycopeptides during this study could be considered before empirical therapy against $B$. cereus infections. PCR analysis of nineteen $B$. cereus isolates showed the presence of haemolytic enterotoxin gene $h b l A(100 \%), h b l C(73.6 \%)$ and $h b l D$ $(89.4 \%)$ and that of non-haemolytic enterotoxin $n h e A(100 \%)$ and $n h e C(100 \%)$. All the isolates were devoid of $n h e B$ gene. Their toxigenicity can further increase the risk of illness due to raw consumption of vegetables for which important interventions should be implemented for decontamination.

\section{Introduction}

The consumption of fresh vegetables meets the demand of dietary nutrients and fiber. The growing trend of its raw consumption in the urban areas necessitates its concern in light of microbial safety. Bacillus cereus, a Grampositive, aerobic-to-facultative, widely distributed environmentally and sporulating ability favours its prevalence in all food types. High incidence of $B$. cereus in raw milk, meat and vegetables in India were suspected in many outbreaks which go unrecognized (Valero et al., 2002; Bedi et al., 2005;
Willayat et al., 2007; Altaf et al., 2012). A wide variety of food poisoning is associated with emetic and diarrheal syndrome caused by Bacillus cereus (Toh et al., 2004; Ceuppens et al., 2011). Fresh water and decaying organic matter are one of the most frequent reservoirs of Bacillus cereus that cause the contamination of growing vegetables through soil leading to the transient colonization of the human intestine (Ghosh 1978; Jensen et al., 2003). 
Uniform resistance to certain antibiotics was observed in Bacillus cereus isolates (Bottone 2010) which can cause perturbation in the empirical therapy during outbreaks. Moreover, the niche colonization of bacteria make the effect more pronounced with horizontal transfer of such antibiotic resistance traits to other non-pathogenic bacteria (Fernández et al., 2011).

The diarrheal type of food poisoning is most common type of food poisoning around the world. The two protein complexes from $B$. cereus responsible for virulence in diarrheal type are haemolysin BL (HBL) and nonhaemolytic enterotoxin (NHE). The haemolysin $\mathrm{BL}$ consists of a binding component $\mathrm{B}$ and two lytic components $\mathrm{L}_{1}$ and $\mathrm{L}_{2}$ responsible for enterotoxigenicity of B. cereus (Beecher et al., 1995). Three genes $h b l A, h b l D$ and $h b l C$ are translated to $\mathrm{B}$ and $\mathrm{L}$ $\left(\mathrm{L}_{1}\right.$ and $\mathrm{L}_{2}$ ) components respectively (Ryan et al., 1997). Another non-haemolytic enterotoxin with three different proteins A, B and $\mathrm{C}$ are encoded by nheA, nheB and nheC genes, respectively (Granum et al., 1999). This study scanned the frequency of genes coding for the two protein complexes (HBL and NHE) in indigenous isolates and antibiotic screening to reach the positive empirical outcome in treating Bacillus cereus infections.

\section{Materials and Methods}

\section{Study area and sampling}

The Buddha Nallah, a natural stream of Sutlej, traversing through Ludhiana city of Punjab state has high Total Dissolved solids $>1000 \mathrm{mg} / \mathrm{L}$, chlorides up to $400 \mathrm{mg} / \mathrm{L}$, Chemical Oxygen Demand $>400 \mathrm{mg} / \mathrm{L}$, Biochemical Oxygen Demand 52-195 mg/L, Most Potable Number up to $2400+$ per $100 \mathrm{ml}$. Villages along the Buddha Nallah are known for vegetables growers. They use irrigation pumps, river or streams for cultivation. Epidemiological surveillance study for the microbiological quality of fresh vegetables was routinely carried out during the vegetable of the season for the period of 2 and $1 / 2$ years (July 2013-December 2015). Water samples from the irrigation pumps were collected according to the standard method of BIS (IS10500:1991).

A total of 420 samples of salad vegetables such as carrot, radish, cucumber, tomato, cabbage, spinach and long melon were procured from village fields along Buddha Nallah. In comparison, 75 samples from supermarkets and 230 samples from street vendors were also collected.

\section{Enumeration of Bacillus cereus}

The fresh vegetable, 25grams of sample was taken and washed with autoclaved water so as to omit any environmental contamination. Vegetable sample was chopped with the help of sterile knife into $2-3 \mathrm{~cm}$ pieces and transferred to the $225 \mathrm{ml}$ water blank. It was shaken vigorously for uniformity and serial dilutions of the suspension were spread onto Bacillus cereus Agar Base supplemented with Polymyxin B sulphate (50000Unit/L) and sterile Egg Yolk Emulsion (25ml/L) (HiMedia Laboratories Pvt. Ltd., Mumbai) [IS-5887(Part 6):1999] plates in triplicates for each dilution and incubated at $37^{\circ} \mathrm{C}$ for $24-48$ hours. Following incubation, all colonies on dishes containing 30-300 colonies were counted per dilution and $\log \mathrm{cfu}^{-1}$ was calculated. The presumed colonies were verified by complete phenotypic characterisation.

\section{Phenotypic characterization}

The isolates were verified as Bacillus cereus by their size, shape, Gram's staining, simple staining, motility and colony morphology, 
biochemical tests, virulence based tests and further confirmed with molecular tools. Antibiotic susceptibility was also evaluated using the Kirby-Bauer disc diffusion method on Mueller Hinton agar with 25 antibiotics belonging to 15 different classes; $\beta$-Lactams, Fluoroquinolones, Aminoglycoside, $1^{\text {st }}$ Generation Cephalosporins, $2^{\text {nd }}$ Generation Cephalosporins, $\quad 3^{\text {rd }} \quad$ Generation Cephalosporins, Chloramphenicol, Tetracycline, Metronidazole, Macrolide, Sulphonamides, Lyncosamides, Glycopeptides, Nitrofurans and Carbapenems.

\section{Bacterial genome extraction}

Genomic DNA was extracted from colonies that were identified as Bacillus cereus with the help of Invitrogen Easy DNA® Isolation Kit (Invitrogen Inc.) as per the manufacturer's protocol from selected bacterial strains grown in nutrient broth for overnight at optimal temperature. DNA was eluted into $100 \mu 1 \mathrm{X}$ TE buffer (Invitrogen Inc.). Quantity and quality of DNA was checked on TECAN 2000 Nanoquant Plate. The DNA of all the samples was diluted to $25 \mathrm{ng} / \mu \mathrm{l}$ by adding nuclease free water and stored at $-20^{\circ} \mathrm{C}$. Alternatively, DNA quality was checked on $0.8 \%$ agarose gel. A single sharp band of DNA signified high quality of DNA. DNA of each sample was diluted to $25 \mathrm{ng}$ per $\mu \mathrm{l}$ of nuclease free water (Promega Inc.) before the PCR assay.

\section{PCR assay}

Uniplex PCR was performed with reaction volume of $30 \mu \mathrm{l}$ for each sample, that

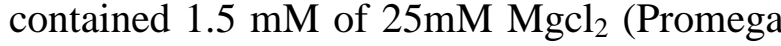
Inc.), $1 X$ Go Taq TM buffer (Promega Inc.), $0.2 \mathrm{mM}$ of dNTPs (Promega Inc.), $0.5 \mu \mathrm{M}$ of each primers (Table 1), 2U of GoTaqTM DNA polymerase (Promega Inc.) and $50 \mathrm{ng} / \mu \mathrm{l}$ of the DNA template. The final volume of the reaction was adjusted with Nuclease free
Water (Promega Inc.). The PCR conditions consisted of a pre-incubation step for $5 \mathrm{~min}$ at $94^{\circ} \mathrm{C}, 35$ cycles of denaturation at $94^{\circ} \mathrm{C}$ for $30 \mathrm{sec}$, annealing step for $30 \mathrm{sec}$ (Table 1) with extension time of $40 \mathrm{sec}$ at $72^{\circ} \mathrm{C}$ and a termination step with a final extension for $7 \mathrm{~min}$ at $72^{\circ} \mathrm{C}$. After amplification, the product was loaded onto the $1.5 \%$ agarose gel, visualized under UV light and photographed using SYNGENE gel documentation system with Gene snap software programme.

\section{Results and Discussion}

\section{MPN Index of vegetables and irrigation water}

During the Food MPN analysis from the village field samples, cucumber samples showed high prevalence $(91 \%)$ of MPN index $>100 / \mathrm{g}$ followed by spinach (84\%), long melon $(83.8 \%)$, carrot $(72.7 \%)$, cabbage $(63.4 \%)$ and radish $(61.1 \%)$ (Table 2$)$. The MPN index for tomato was not determined due to the acidic properties of the vegetable which gives false positive result.

In samples collected from Supermarkets, high MPN index of $>100 / \mathrm{g}$ was found in $83.3 \%$ of the radish samples followed by cucumber and long melon (75\%), spinach $(71.4 \%)$, cabbage (44\%) and $42.8 \%$ in carrot (Table 2).

With respect to samples sourced from street vendors, all carrot samples were found to have $>100 / \mathrm{g}$ of MPN index while spinach samples showed lowest prevalence of $70 \%$ samples with $>100 / g$ of MPN index.

$73.33 \%$ salad, ready to eat samples and water contaminated with total and faecal coliform bacteria used in the kitchen of various restaurants from Chittagong city, Bangladesh were reported in 2011. The presence of faecal coliform in supply water indicates direct or indirect contamination from faecal origin. 
Manure is commonly applied to fields in order to dispose off animal waste and to fertilize soils. Enteric pathogens can survive for prolonged periods of time in animal faeces (Hutchison et al., 2004) and may serve as potential inoculum onto plants in the field. Bacillus cereus, a spore former can persist in soil for many years and can even withstand pasteurization at $70^{\circ} \mathrm{C}$ for hours in cattle manure (Marañón et al., 2006). Therefore, microbial assessment of the manure should gain immense importance in stringent sanitation management strategies as these bacteria are opportunistic and become virulent during animal or human contact.

Similarly, water for irrigation has utilized faecal coliform as an indicator of acceptable quality. Total coliform and fecal coliform MPN count was determined to be $>10 / \mathrm{ml}$ in most of the samples with highest positive percentage of 98.5 and 91.2 for cucumber and spinach respectively (Table 2). The Indian environment ministry recommended desirable limit of faecal coliform at 1,000 MPN/100ml and a maximum permissible limit at 10,000 MPN/100ml for discharge of treated sewage into a water body or reuse for agriculture.

Our study has shown the imminence of contaminated water used for irrigation. The total coliform as well as faecal coliform were found above the desirable limit. It was observed that all vegetable growing areas (village fields) around Buddha Nallah have contaminated ground water with high MPN index of $>10 / \mathrm{ml} \quad(1000 / 100 \mathrm{ml})$ (Table 2) which is undesirable for irrigation purpose. Crop irrigation and application of pesticides with contaminated water also are considered as primary sources of inoculum in the field (Brandl, 2006). Water can predispose the coliform to the fields if the ground water is mixed with the sewage, runoff water in from immediate vicinity of livestock and use of untreated manure into the fields. Owing to dissemination of pathogens into the field, greater risk may establish which aids reaching the pathogens to their threshold of virulence with increase in nutrient abundance.

\section{Occurrence of Bacillus cereus}

Out of 420 vegetable samples collected from village fields, 246 (58.6\%) were positive for Bacillus cereus which was higher than its percent occurrence in supermarket samples $(30 / 75,40.7 \%)$. The percent contamination increased by $7.9 \%$ in vendor samples.

Cucumber samples from village fields had shown highest percent contamination by $B$. cereus $(75 \%)$ followed by $50 \%$ in case of radish and long melon from supermarkets and $77.77 \%$ in Long melon collected from street vendors (Fig. 1).

Up to $30 \%$ food samples were reported positive for $B$. cereus in processing plant (Kim et al., 2016) (raw material, salads in washing steps, and final products) which were substantially less than the results found in this study. The high contamination of irrigation water, Bacillus spores in soil and use of untreated animal manure is the suggestive of this high prevalence of Bacillus cereus in vegetables.

The high percentage and high mean count of Bacillus cereus in samples collected from vendors can occur at any step during packaging, storage, transportation, poor handling and vending operations. Spores being hydrophobic in nature may stick to the vegetable surface (Anderson et al., 1998) and germinate whenever the ideal conditions are set. Furthermore, the rise in population of bacteria may occur due to the spore germination into vegetative phase on the surface/internal part of the vegetable during temperature abuse, nutrient availability and sprinkling of water over the fresh produce to retain its freshness and consumer acceptability during vending operations. 
Table.1 List of primers used for targeting species specific virulent genes of Bacillus cereus

\begin{tabular}{|c|c|c|c|c|}
\hline Gene & Primer sequence $\left(5^{\prime} \rightarrow 3^{\prime}\right)$ & Product size (bp) & Annealing temp. & Reference \\
\hline hblA & F-GTGCAGATGTTGATGCCGAT & 320 & $56^{\circ} \mathrm{C}$ & Banerjee et al (2011) \\
\hline$h b l D$ & $\begin{array}{l}\text { F- AATCAAGAGCTGTCACGAAT } \\
\text { R-CACCAATTGACCATGCTAAT }\end{array}$ & 430 & $52^{\circ} \mathrm{C}$ & $-d o-$ \\
\hline$h b l C$ & $\begin{array}{l}\text { F- AATGGTCATCGGAACTCTAT } \\
\text { R-CTCGCTGTTCTGCTGTTAAT }\end{array}$ & 750 & $52^{\circ} \mathrm{C}$ & $-d o-$ \\
\hline nheA & $\begin{array}{l}\text { F- TACGCTAAGGAGGGGCA } \\
\text { R- GTTTTTATTGCTTCATCGGCT }\end{array}$ & 500 & $52^{\circ} \mathrm{C}$ & $-d o-$ \\
\hline$n h e B$ & $\begin{array}{c}\text { F- CTATCAGCACTTATGGCAG } \\
\text { R-ACTCCTAGCGGTGTTCC }\end{array}$ & 770 & $52^{\circ} \mathrm{C}$ & $-d o-$ \\
\hline nheC & $\begin{array}{l}\text { F- CGGTAGTGATTTGCTGGG } \\
\text { R-CAGCATTCGTACTTGCCAA }\end{array}$ & 582 & $52^{\circ} \mathrm{C}$ & $-d o-$ \\
\hline
\end{tabular}

Table.2 Microbial analysis of different vegetables among three sources

\begin{tabular}{|c|c|c|c|c|c|}
\hline \multirow[b]{2}{*}{ Vegetables } & \multirow[b]{2}{*}{ Source } & \multicolumn{4}{|c|}{ Water quality Index } \\
\hline & & $\begin{array}{c}\text { Mean MPN index } \\
\text { of food }^{b}>100 / g\end{array}$ & $\begin{array}{c}\text { Total coliforms } \\
>10 / \mathrm{ml}\end{array}$ & $\begin{array}{c}\text { Faecal coliforms } \\
>10 / \mathrm{ml}\end{array}$ & $\begin{array}{l}\text { Bacillus cereus } \\
\text { count }^{\mathrm{a}}\left(\log \text { cfu }^{-1}\right)\end{array}$ \\
\hline \multirow[t]{3}{*}{ Carrot } & Village field & 72.7 & 90.1 & 68.1 & 4.35 \\
\hline & Supermarket & 42.8 & ND & ND & 2.68 \\
\hline & Street vendors & 100 & ND & ND & 2.75 \\
\hline \multirow[t]{3}{*}{ Radish } & Village field & 61.1 & 86.5 & 70.1 & 3.06 \\
\hline & Supermarket & 83.3 & ND & ND & 2.67 \\
\hline & Street vendors & 94.1 & ND & ND & 2.91 \\
\hline \multirow[t]{3}{*}{ Cucumber } & Village field & 91 & 98.5 & 74.6 & 2.69 \\
\hline & Supermarket & 75 & ND & ND & 2.56 \\
\hline & Street vendors & 82.3 & ND & ND & 3.01 \\
\hline \multirow[t]{3}{*}{ Tomato } & Village field & ND & 75.6 & 64.9 & 3.09 \\
\hline & Supermarket & ND & ND & ND & 2.58 \\
\hline & Street vendors & ND & ND & ND & 2.79 \\
\hline \multirow[t]{3}{*}{ Cabbage } & Village field & 63.4 & 86.5 & 59.6 & 2.37 \\
\hline & Supermarket & 44.4 & ND & ND & 2.68 \\
\hline & Street vendors & 86.3 & ND & ND & 2.88 \\
\hline \multirow[t]{3}{*}{ Spinach } & Village field & 84 & 96 & 91.2 & 3.12 \\
\hline & Supermarket & 71.4 & ND & ND & 2.55 \\
\hline & Street vendors & 70 & ND & ND & 3.62 \\
\hline \multirow[t]{3}{*}{ Long melon } & Village field & 83.8 & 98.3 & 79 & 2.73 \\
\hline & Supermarket & 75 & ND & ND & 2.08 \\
\hline & Street vendors & 80 & ND & ND & 3.11 \\
\hline
\end{tabular}

a- level of significance at $\mathrm{p}<0.05$

b- Desirable limit is $100 / \mathrm{g}$

c- Desirable limit is $10 / \mathrm{ml}$

$\mathrm{ND}=$ Not Determined (low $\mathrm{pH}$ of Tomato gives false positive results, true representative of water sample for vegetables washing could not be produced) 
Fig.1 Percent incidence of Bacillus cereus among vegetables and sources

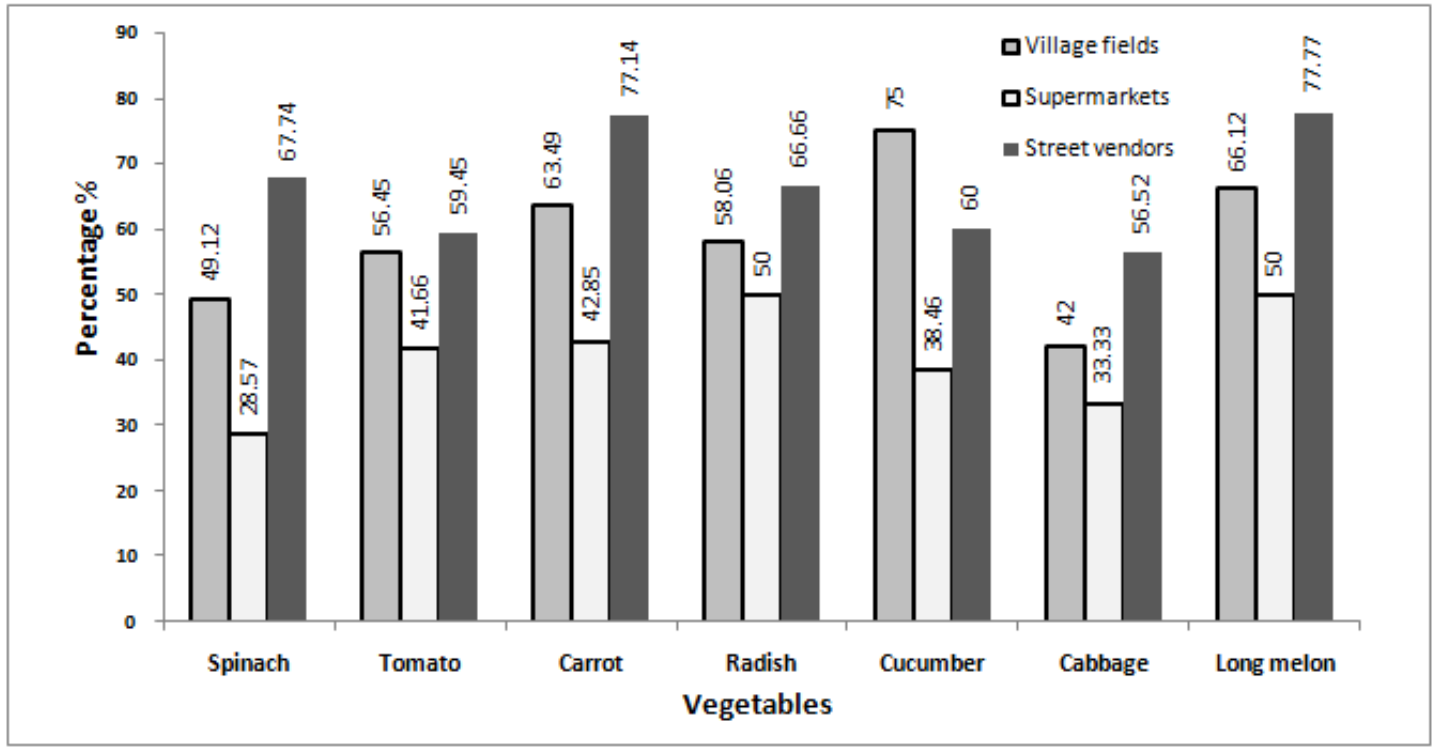

Fig.2 Percent frequency of antibiotic resistance exhibited by Bacillus cereus isolates

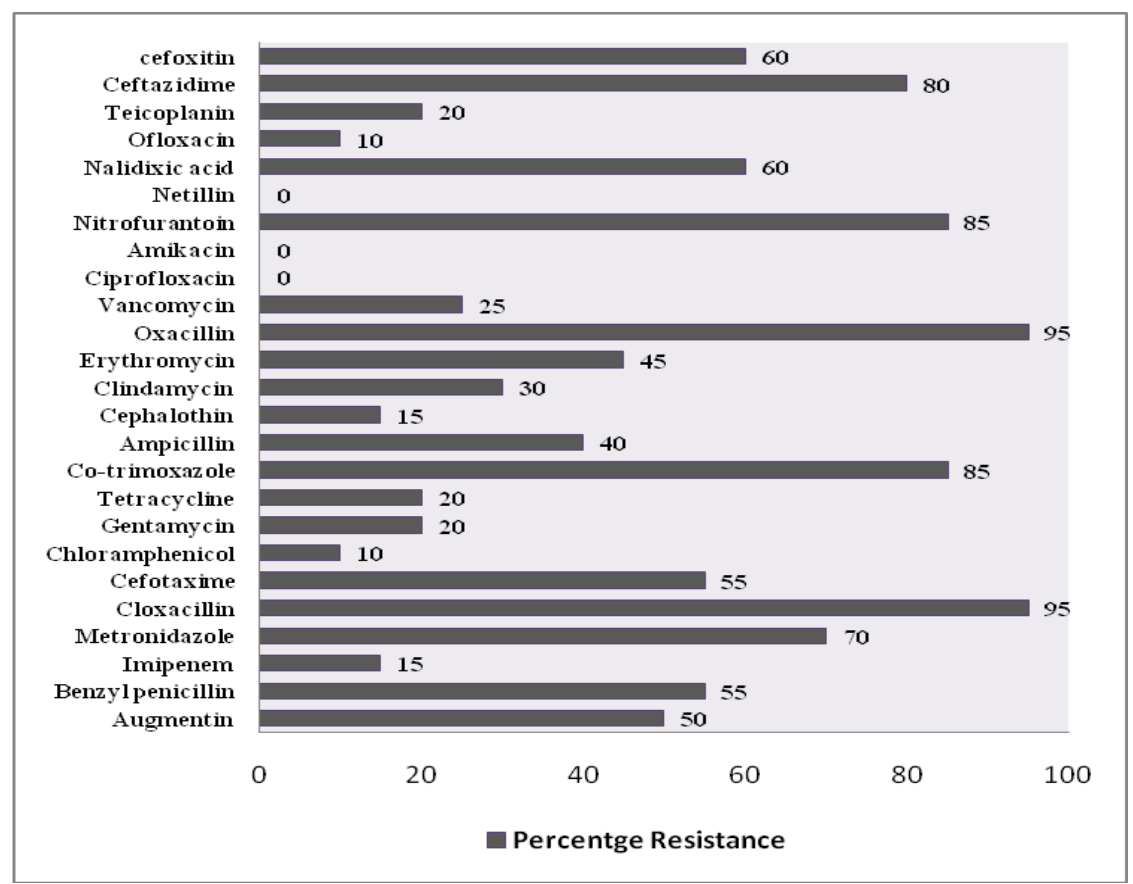


Fig.3 Electrophoretic gel imaging of $h b l A$ gene (320bp fragment) showing $M$ lane $=1 \mathrm{kbp}$ ladder (Invitrogen); Lanes 2-5=Bacillus cereus isolates showing the hblA gene and Lane 1= Positive control of Bacillus cereus MTCC 430

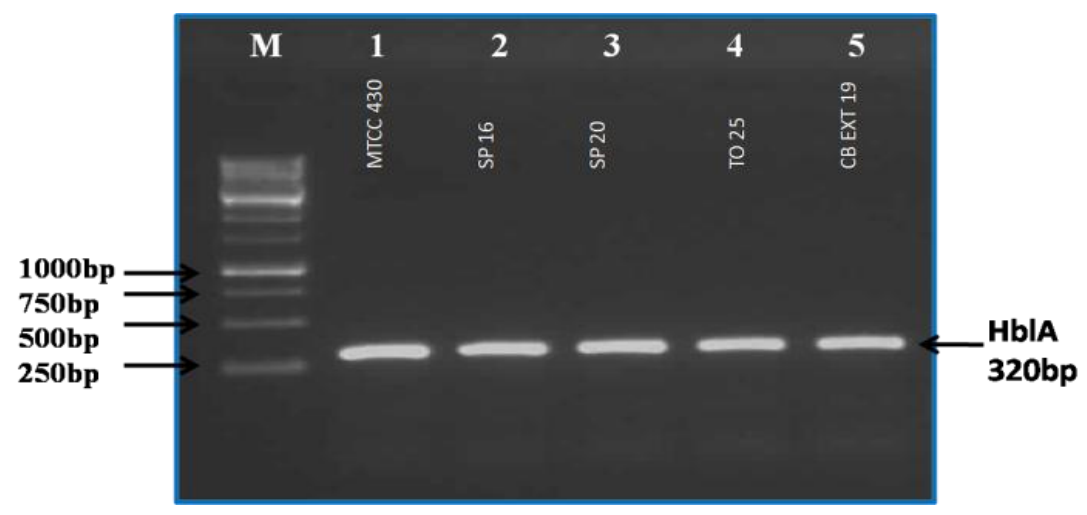

Fig.4 Electrophoretic gel imaging of $h b l C$ gene (750bp fragment) showing $\mathrm{M}$ lane= $1 \mathrm{kbp}$ ladder (Invitrogen); Lanes 2-7=Bacillus cereus isolates showing the $h b l C$ gene and Lane $1=$ Positive control of Bacillus cereus MTCC 430

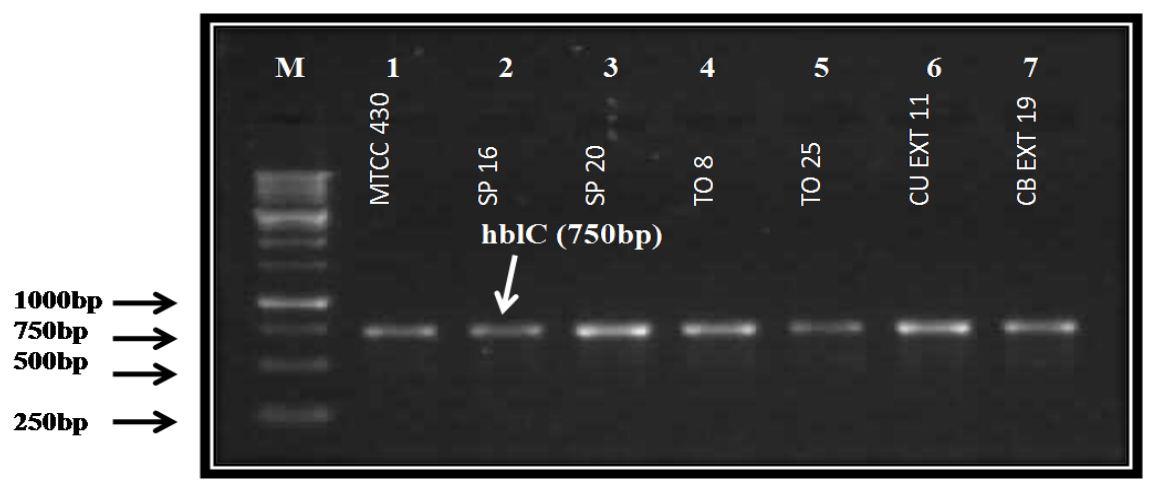

Fig.5 Electrophoretic gel imaging of $h b l D$ gene (430bp fragment) showing M lane= $1 \mathrm{kbp}$ ladder (Invitrogen); Lanes 1-18=Bacillus cereus isolates showing the hblD gene and Lane 19= Positive control of Bacillus cereus MTCC 430

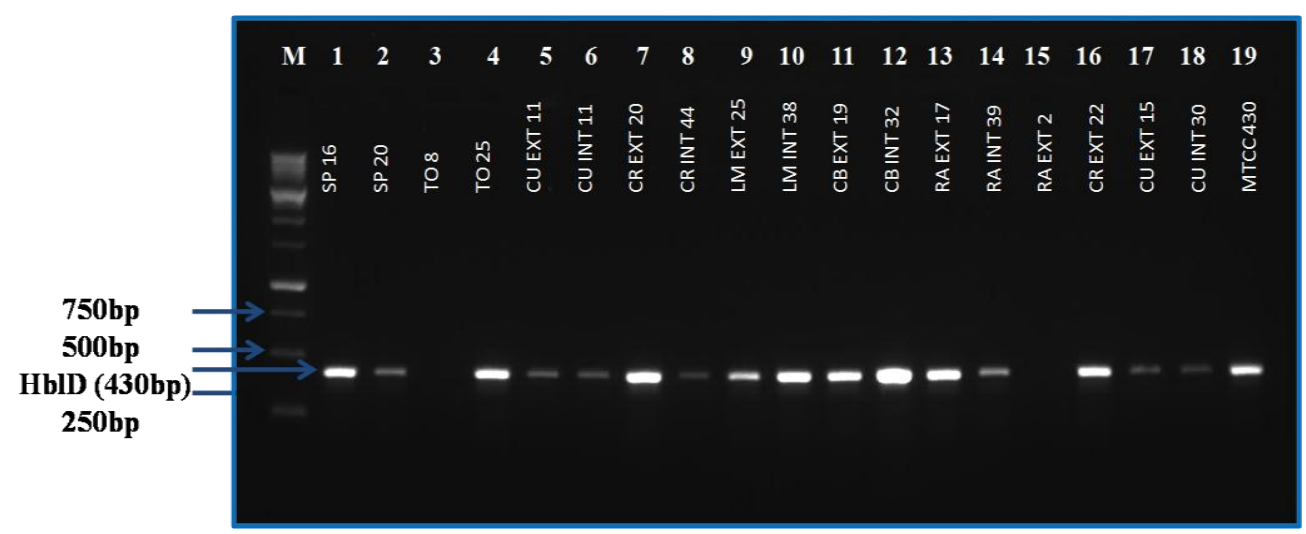


Fig.6 Electrophoretic gel imaging of $n h e A$ gene (500bp fragment) showing $\mathrm{M}$ lane= 1kbp ladder (Invitrogen); Lanes 2-18=Bacillus cereus isolates showing the nheA gene and Lane 1= Positive control of Bacillus cereus MTCC 430

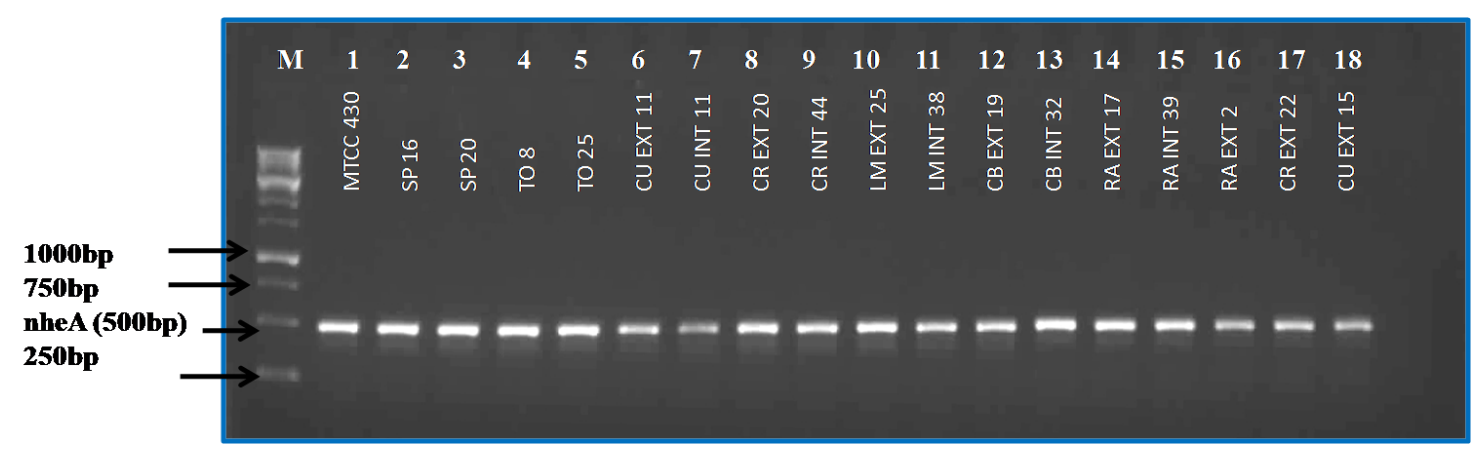

Fig.7 Electrophoretic gel imaging of $n h e C$ gene (582bp fragment) showing $\mathrm{M}$ lane $=1 \mathrm{kbp}$ ladder (Invitrogen); Lanes 2-6=Bacillus cereus isolates showing the $n h e C$ gene and Lane 1= Positive control of Bacillus cereus MTCC 430

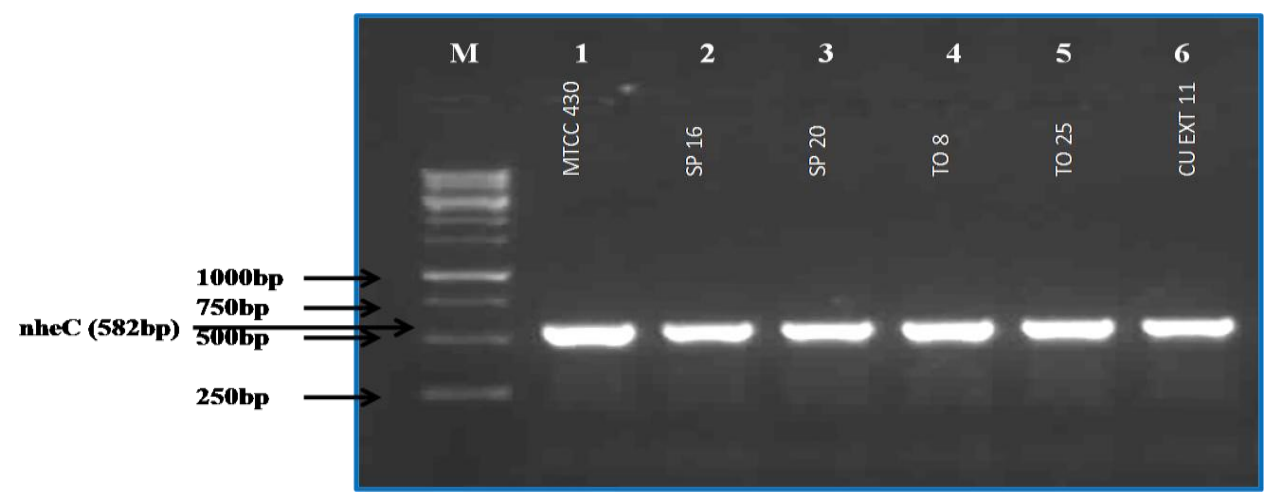

\section{Enumeration of Bacillus cereus}

Bacillus cereus was found in low mean count (2.37 $\log \mathrm{cfu} \mathrm{g}^{-1}$ ) only in cabbage samples from village fields, rest of the vegetables supported better growth of B. cereus (2.69$4.35 \log \mathrm{cfu} \mathrm{g}^{-1}$ ) (Table 2).

In case of supermarket samples, the mean count was found highest in radish and cabbage (2.68 $\log \mathrm{cfu} \mathrm{g}^{-1}$ ) and lowest in long melon $\left(2.08 \log \mathrm{cfu} \mathrm{g}^{-1}\right)$. Spinach samples from street vendor on the other hand, were found most contaminated (3.62 log cfu g $\left.\mathrm{g}^{-1}\right)$ by $B$. cereus than other vegetables tested. $B$. cereus didn't proliferate much in carrot samples (2.75 log cfu g ${ }^{-1}$ ) (Table 2).
Vegetables irrigated with river water had shown $32.7 \%$ contamination with Bacillus species (Weldezgina and Muleta, 2016). B. cereus was reported to be present in 27.3$30.8 \%$ of food samples in processing plant (raw material, salads in washing steps, and final products) (Kim et al., 2016).

The contamination levels of $B$. cereus in cucumbers, carrots and peppers ranged from 2-3.89 $\log \mathrm{cfu} \mathrm{g}^{-1}$ which are in agreement to this study. These levels were sufficient to initiate growth of $B$. cereus strains and spoilage of the vegetables.

The study depicts that cropping vegetables in area around Buddha Nallah are highly 
contaminated with $B$. cereus and is a serious health burden.

\section{Phenotypic characterization}

All Bacillus strains were haemolytic in nature and could hydrolyse Esculin, reduce nitrate, ferment malonate and glucose.

Bacillus cereus isolates from fresh vegetable samples were found resistant to Cloxacillin (5mcg) (95\%), Oxacillin (1 mcg) (95\%), CoTrimoxazole (25 mcg) (85\%), Nitrofurantoin (300 mcg) (80\%), Ceftazidime $(30 \mathrm{mcg})$ (80\%), Metronidazole (5 mcg) (70\%), Nalidixic Acid (30 mcg) (60\%), Cefoxitin (30 mcg) (60\%), Benzyl penicillin (2 mcg) $(55 \%)$ and Cefotaxime $(30 \mathrm{mcg})(55 \%)$. The other antibiotics showed low resistance $(<45 \%)$ to the isolates tested but no resistance to Netillin (30 mcg), Amikacin (30 mcg) and Ciprofloxacin (5 mcg) (Fig. 2).

The antimicrobial resistance pattern in 35 Bacillus cereus strains and found high resistance to $\beta$-lactam antibiotics, including ampicillin, cefepime, oxacillin, and penicillin while completely susceptible to gentamycin, clindamycin, vancomycin, ciprofloxacin, imipenem (94\%), chloramphenicol (89\%), tetracycline $(54 \%)$ and erythromycin $(97 \%)$ (Chon et al., 2012). Results showed that three antibiotics named netillin, amikacin (aminoglycoside) and ciprofloxacin were most efficacious with no resistance pattern found for the tested $B$. cereus isolates. Furthermore, only $20-25 \%$ resistance was observed when subjected to glycopeptides (Teicoplanin and Vancomycin) and tetracycline which corroborates its application in any future complications in bacterial infection.

Results in this study are in conformity with the finding of many researchers (Wong et al., 1988; Weber et al., 1988; Bottone, 2010;
Ikeda et al., 2015; Tatsinkou-Fossi et al., 2016) except for nalidixic acid in which no resistance was reported in previous studies. Most B. cereus isolates are resistant to penicillins and cephalosporins as a consequence of $\beta$-lactamase production (Bottone 2010). The study, however, contradict the findings in which more than half of the isolates were resistant to clindamycin and all to ampicilin (Ikeda et al., 2015). High resistance to the multiple antibiotics could represent high mortality and can pave an opportunity for epidemic outbreaks which are tough to circumvent. During Bacillus infections such as Blood stream infection (BSI) (Ikeda et al.2015) and gastrointestinal-tract infections ${ }^{11}$, susceptibility pattern of aminoglycosides, fluoroquinones, tetracycline and glycopeptides could be considered along with the empirical therapy.

The multiple drug resistance was observed with MAR index for all the Bacillus cereus isolates in the range of $0.16-0.68$ with an average of 0.41 . The only Bacillus cereus strain with $<0.2$ MAR index was isolated from Spinach sample while others were having MAR of >2.0. All the Bacillus cereus isolates were found resistance to not less than 4 antibiotics and the resistance count increased up to 17 antibiotics.

The percentage occurrence of multiple antibiotic resistances was highest $(25 \%)$ with 0.32 index followed by $20 \%$ isolates with MAR 0.68 (not shown). None of the isolate was found complete resistant to all the antibiotics tested. High MAR index clearly reflects the indiscriminate use of antibiotics in non-strategic healthcare services. More elaborately, multiple resistances could be due to the expression of resistance genes present in the bacteria or resistance genes channelled from other bacterial species through horizontal gene transfer. Conveyance of these 
genes by plasmid was elucidated for tetracycline resistance in Bacillus cereus (Rather et al., 2012) which means that these genes significantly affect the resistant phenotype. The source of bacteria is also the concerning factor for example; clinical samples of $S$. aureus (Rajaduraipandi et al., 2006) and E. coli (Hora and Ali, 2014) were reported to be multiple drug resistant.

\section{Molecular detection of Bacillus cereus and its virulence gene distribution}

Nineteen isolates were identified for virulence genes present in $B$. cereus with positive control of $B$. cereus MTCC430. The haemolysin gene hblA (320bp) (Fig. 3), hblC (750bp) (Fig. 4) and hblD (430bp) (Fig. 5) were found in $100 \%$ (19), $73.6 \%$ (14), $89.4 \%$ (17) isolates respectively. Two of the nonhaemolytic enterotoxin genes nheA (500bp) (Fig. 6) and nheC (582bp) (Fig. 7) were present in all the isolates tested while no nheB (770bp) gene was detected at all.

Similar haemolytic enterotoxin gene profiling was reported from RTE vegetables (Chon et al., 2015; Banerjee et al., 2011) and that of non-haemolytic enterotoxin gene of B. cereus isolated from milk (Banerjee et al., 2011; Abbas et al., 2014). These enterotoxins are related to outbreaks of food borne disease; enterotoxin- $T$ has been classified as enterotoxin on the basis of genetic and structural relationship with bacterial enterotoxins (Agata et al., 1995). Production of both $\mathrm{Hbl}$ and Nhe is believed to be restricted to members of the B. cereus group (From et al., 2005).

In this study B. cereus strains $(94.7 \%)$ showed continuous haemolytic patterns. The presence of $h b l A$ gene in all strains can be correlated with this pattern. B. cereus causes selflimiting (24-48 h) food-poisoning syndromes (a diarrheal type and an emetic type) (Tewari and Abdullah, 2015).
The diarrheic syndromes in patients are suspected to occure due to three toxins: hemolysin BL (Hbl), nonhemolytic enterotoxin (Nhe) and cytotoxin K (CytK) that cause intestinal fluid secretion, probably by several mechanisms, including pore formation and activation of adenylatecyclase enzymes (Guinebretière and Broussolle, 2002; Jalalpour 2012).

B. cereus contaminated food; emetic type of food poisoning has been largely associated with the consumption of rice and pasta, while the diarrheal type is transmitted mostly by milk products, vegetables and meat (Murray et al., 2006; Logan and Rodrigez-Diaz, 2006).

Bacillus cereus was found in high count in vegetables and showed their virulence in terms of lysis of erythrocytes and presence of gene encoding for haemolytic and nonhaemolytic enterotoxin. Both the patterns along with the resistance in antibiotic response can further complicate the availability of possible interventions against illness by these bacteria. The presence of enterotoxin of haemolytic as well as nonhaemolytic type may contribute to the Bacillus infections which should be assessed by in-vitro toxicity assay so that empirical intervention could be adopted at the earliest.

The present study surveillance of raw vegetables from village fields around Buddha Nullah has revealed the high health concerns due to contamination with $B$. cereus. The recovered isolates were found haemolytic which can be established by presence of haemolytic genes in their genome. Along with, genes encoding for non-haemolytic enterotoxin were also detected. The expression of such genes in the mammalian cells and resistance to many antibiotics could potentially cause illness which will be difficult to circumvent. The data in study provides useful information for public health 
management policies. The proper sanitation strategies should be established so as to prevent the outbreaks related to consumption of fresh vegetables.

\section{References}

Abbas, B.A., Khudor, M.H. and Saeed, B.M. (2014). Detection of $h b l$, nhe and bceT Toxin Genes in Bacillus cereus Isolates by Multiplex PCR. International Journal of Current Microbiology and Applied Sciences 3(11):1009-1016.

Agata, N., Ohta, M., Arakawa, Y. and Mori, M. (1995). The bceT gene of Bacillus cereus encodes an enterotoxic protein. Microbiology 141(4):983-988.

Altaf, M.S., Iqbal, A., Ahmad, M., Hussain, S.A., Ahmad, R. and Willayat, M.M. (2012). Study of enterotoxigenicity of B.cereus emetic strain by skin vasopermeability reaction in rabbits and poultry. International Journal of Pharma and Bio Sciences 3(2):166172.

Anderson, A., Granum, P.E. and Ronner, U. (1998). The adhesion of Bacillus cereus spores to epithelial cells might be an additional virulence mechanism. International Journal of Food Microbiology 39:93-99.

Banerjee, M., Nair, G.B. and Ramamurthy, T. (2011). Phenotypic and genetic characterization of Bacillus cereus isolated from the acute diarrhoeal patients. Indian Journal of Medical Reserch 133(1):88-95.

Bedi, S.K., Sharma, C.S., Gill, J.P.S., Aulakh, R.S. and Sharma, J.K. (2005). Incidence of enterotoxigenic $B$. cereus in milk and milk products. Journal of Food Science and Technology 42(3):272-275.

Beecher, D.J., Schoeni, J.L. and Wong, A.C. (1995). Enterotoxic activity of hemolysin BL from Bacillus cereus. Infection and Immunology 63:44234428.

Bottone, E.J. (2010). Bacillus cereus, a Volatile Human Pathogen. Clinical Microbiology Reviews 23(2):382-398.

Brandl, M.T. (2006). Fitness of human enteric pathogens on plants and implications for food safety 1. Annual Review of Phytopathology 44:367-392.

Ceuppens, S., Rajkovic, A., Heyndrickx, M., Tsilia, V., Van de Wiele, T., Boon, N. and Uyttendaele, M. (2011). Regulation of toxin production by Bacillus cereus and its food safety implications. Critical Reviews in Microbiology 37:188-213.

Chon, J.W., Kim, J.H., Lee, S.J., Hyeon, J.Y. and Seo, K.H.(2012). Toxin profile, antibiotic resistance, and phenotypic and molecular characterization of Bacillus cereus in Sunsik. Food Microbiology 32:217-222.

Chon, J.W., Yim, J.H., Kim, H.S., Kim, D.H., Kim, H., Oh, D.H., Kim, S.K. and Seo, K.H. (2015). Quantitative Prevalence and Toxin Gene Profile of Bacillus cereus from Ready-to-Eat Vegetables in South Korea. Foodborne pathogens and disease 12(9):795-799.

Fernández, L., Breidenstein, E.B. and Hancock, R.E. (2011). Creeping baselines and adaptive resistance to antibiotics. Drug Resistance Updates 14(1):1-21.

From, C., Pukall, R., Schumann, P., Hormazabal, V. and Granum, P.E. (2005). Toxin-producing ability among Bacillus spp. outside the $B$. cereus group. Applied and Environmental Microbiology 71:11781183.

Ghosh, A.C. (1978). Prevalence of Bacillus cereus in the faeces of healthy adults. 
Journal of Hygiene (Lond.) 80:233236.

Granum, P.E., O'Sullivan, K. and Lund, T. (1999). The sequence of the nonhemolytic enterotoxin operon from Bacillus cereus. FEMS Microbiology Letters 177:225-229

Guinebretière, M.H. and Broussolle, V. (2002). Enterotoxigenic profiles of food-poisoning and food-borne Bacillus cereus strains. Journal of Clinical Microbiology 40(8):30533056.

Hora, S. and Ali, Z. (2015). A study of relationship between antibiotic resistance and molecular characteristics of Escherichia coli isolates obtained from different human clinical specimens against multiple antibiotic resistance (MAR) index in Bareilly (India) region. International Journal of Pharmaceutical Sciences and Research 3(9):3331-3336.

Hutchison, M.L., Walters, L.D., Moore, A., Crookes, K.M. and Avery, S.M. (2004). Effect of length of time before incorporation on survival of pathogenic bacteria present in livestock wastes applied to agricultural soil. Applied and Environmental Microbiology 70:51115118.

Ikeda, M., Yagihara, Y., Tatsuno, K., Okazaki, M., Okugawa, S., Moriya, K. (2015). Clinical characteristics and antimicrobial susceptibility of Bacillus cereus blood stream infections. Annals of Clinical Microbioliology and Antimicrobials 14(1):1.

Jalalpour, S. (2012). Food borne diseases bacteria; frequency antibiotic resistance bacteria in Iranian foods. African Journal of Microbiology Research 6(4):719-723

Jensen, G.B., Hansen, B.M., Ellenberg, J. and Mahillon, J. (2003). The hidden lifestyles of Bacillus cereus and relatives. Environmental Microbiology 5:631-640.

Kim, H.J., Koo, M., Hwang, D., Choi, J.H., Kim, S.M. and Oh, S.W. (2016). Contamination patterns and molecular typing of Bacillus cereus in fresh-cut vegetable salad processing. Applied Biological Chemistry 59(4):573-577.

Logan, N.A and Rodrigez-Diaz, M. (2006). Bacillus spp. and related genera. In: Gillespie, S.H. and Hawkey, P.M. (eds) Principles and practice of clinical bacteriology, 2nd edn. John Wiley and Sons Ltd, West Sussex, pp 139-158.

Maranon, E., Castrillon, L., Fernández, J. J., Fernández, Y., Peláez, A. I. and Sanchez, J. (2006). Anaerobic mesophilic treatment of cattle manure in an upflow anaerobic sludge blanket reactor with prior pasteurization. Journal of Air and Waste Management Association 56(2):137-143.

Murray, P.R., Baron, E.J., Jorgensen, J.H., Landry, M.L. and Pfaller, M.A. (2007). Manual of clinical microbiology, 9th edn. American Society of Microbiology Press, Washington DC.

Rajaduraipandi, K., Mani, K.R., Panneerselvam, K., Mani, M., Bhaskar, M. and Manikandan, P. (2006). Prevalence and antimicrobial susceptibility pattern of methicillin resistant Staphylococcus aureus: a multicentre study. Indian Journal of Medical Microbiology 24: 38-38.

Rather, M.A., Aulakh, R. S., Gill, J.P.S., Mir, A.Q. and Hassan, M.N. (2012). Detection and sequencing of plasmid encoded tetracycline resistance determinants (tetA and tetB) from food-borne Bacillus cereus isolates. Asian Pacific Journal of Tropical Disease 5(9):709-712. 
Ryan, P.A., Macmillan, J.D. and Zilinskas, B.A. (1997). Molecular cloning and characterization of the genes encoding the $\mathrm{L} 1$ and $\mathrm{L} 2$ components of hemolysin BL from Bacillus cereus. Journal of Bacteriology 179:25512556.

Tatsinkou Fossi, B., Tatah Kihla Akoachere, J.F., Nchanji, G.T. and Wanji, S. (2016). Occurrence, heat and antibiotic resistance profile of Bacillus cereus isolated from raw cow and processed milk in Mezam Division, Cameroon. International Journal of Dairy Technology 68:1-9.

Tewari, A. and Abdullah, S. (2015). Bacillus cereus food poisoning: international and Indian perspective. Journal of food Science and Technology 52(5):2500-2511.

Toh, M., Moffitt, M., Henrichsen, L., Raftery, M., Barrow, K., Cox, J., Marquis, C and Neilan, B. (2004). Cereulide, the emetic toxin of Bacillus cereus, is putatively a product of nonribosomal peptide synthesis. Journal of Applied Microbiology 97:992-1000.

Valero, M., Hernández-Herrero, L.A., Fernández, P.S. and Salmerón, M.C.
(2002). Characterization of Bacillus cereus isolates from fresh vegetables and refrigerated minimally processed foods by biochemical and physiological tests. Food Microbiology 19(5):491-499.

Weber, D.J., Saviteer, S.M., Rutala, W.A. and Tomann, C.A. (1988). In vitro susceptibility of Bacillus spp. to selected antimicrobial agents. Antimicrobial Agents and Chemotherapy 32:642-645.

Weldezgina, D. and Muleta, D. (2016). Bacteriological Contaminants of Some Fresh Vegetables Irrigated with Awetu River in Jimma Town, South Western Ethiopia.

Willayat, M.M., Sheikh, G.N. and Misgar, G.R. (2007). Prevalence of $B$ cereus biotypes in raw and cooked mutton. Journal of Veterinary Public Health 5(2):123-125.

Wong, H.C., Chang, M.H. and Fan, J.Y. (1988). Incidence and Characterization of Bacillus cereus isolates contaminating dairy products. Applied and Environmental Microbiology 54(3):699-702.

\section{How to cite this article:}

Bhavish Sood, Param Pal Sahota and Mandeep Hunjan. 2017. Multidrug Resistant Bacillus cereus in Fresh Vegetables: A Serious Burden to Public Health. Int.J.Curr.Microbiol.App.Sci. 6(4): 649-661. doi: https://doi.org/10.20546/ijcmas.2017.604.080 